\title{
HISTOPATHOLOGY OF DIARTHRODIAL JOINTS IN ANKYLOSING SPONDYLITIS
}

\author{
BY \\ B. CRUICKSHANK \\ From the Department of Pathology and the Rheumatic Research Unit, \\ University of Edinburgh
}

The literature on the pathology of ankylosing spondylitis contains only three articles in which the histopathology of diarthrodial joints is described (Güntz, 1933; Freund, 1942; Collins, 1949). Furthermore, these papers are concerned mainly with pathologically late and clinically inactive stages of the disease and have few illustrations. Despite the lack of adequate pathological study, it is widelyheld that ankylosing spondylitis is a variant of rheumatoid arthritis, rather than a separate disease. The objects of this paper are therefore:

(a) to describe and illustrate in detail the histopathology of the diarthrodial joints in ankylosing spondylitis, particularly in clinically active cases,

(b) to discuss the relationship between ankylosing spondylitis and rheumatoid arthritis as they affect this type of joint.

\section{Material}

Tissue was obtained from twelve cases of ankylosing spondylitis. Three examples were from post-mortem studies, and the other nine were obtained at operation.

The first post-mortem case was exceptional in being clinically active at the time of death and in the number of joints involved. Practically every joint in the body was affected, most of them showing some degree of ankylosis. This case was extensively studied and histological examination included several blocks from the right knee, one from all joints of the first right toe and the right medial cuneiform-first metatarsal joint, several from each sacro-iliac joint, one from each sterno-clavicular joint, one from each of several costo-sternal joints, and several from the manubrio-sternal joint. The spinal column from the ninth thoracic to the third sacral vertebrae was removed at autopsy and blocks were taken from many intervertebral joints, intervertebral disks and the left tenth costo-vertebral joint. Many of the illustrations are taken from this case (Figs 8, 10-14, 16, 18).

Only axial joints were involved in the second post-mortem case; the spinal column from $\mathrm{T} 3$ to L4, the sternal joints, and the symphysis pubis were examined in detail.

The third post-mortem case was that already reported by Freund (1942), many sections from the lumbar vertebrae being available.

The operation material was obtained from the hips of six patients, and from the sternoclavicular, sacro-iliac, and knee joints in one case each. The material from the hips, which consisted of the head of the femur, soft tissue, and acetabular tissue, was taken from both hips in three cases and from one hip only in the other three.

This material was compared with tissue from joints, bursae, and tendon sheaths from 42 cases of rheumatoid arthritis, 42 of other rheumatic diseases (including rheumatic fever, osteo-arthritis, gout, systemic lupus erythematosus, and polyarteritis 
nodosa), 139 of non-rheumatic arthritis (including bacterial arthritis and synovial lesions associated with trauma and damage to menisci), 121 of bursitis, and 137 of tenosynovitis.

\section{Results}

Synovial Tissue.-The changes in the synovial tissue were seen at an early stage in some of the biopsies. It showed proliferation with an excessive number of villi plus hyperplasia of the surface cells, so that this layer was up to six cells deep in places (Figs 1 and 3). The cells were often increased in size, with considerable variation in the size, shape, and chromatin content of the nuclei. Multinucleate cells, sometimes much larger than the mononucleate cells, were present in two cases (Fig. 3), but no mitotic figures were seen. Occasional segments

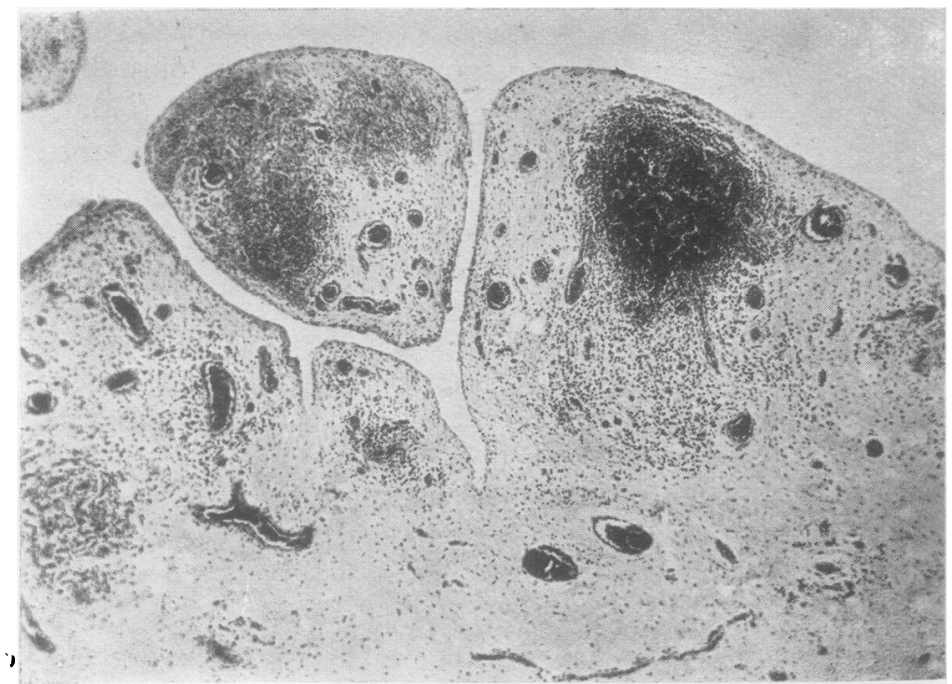

Fig. 1.-Synovial tissue from left hip. Villi increased in number and size, with slight proliferation and patchy necrosis of surface cells (left). Several large foci of lymphocytes and plasma cells areseen. Vessels markedly congested. Some oedema. $(\times 35$.

Fig. 2.-Same section as Fig. 1. Highpower view of focus of lymphocytes and plasma cells. Arrow indicates Russell bodies associated with one plasma cell. $(\times 450$. $)$

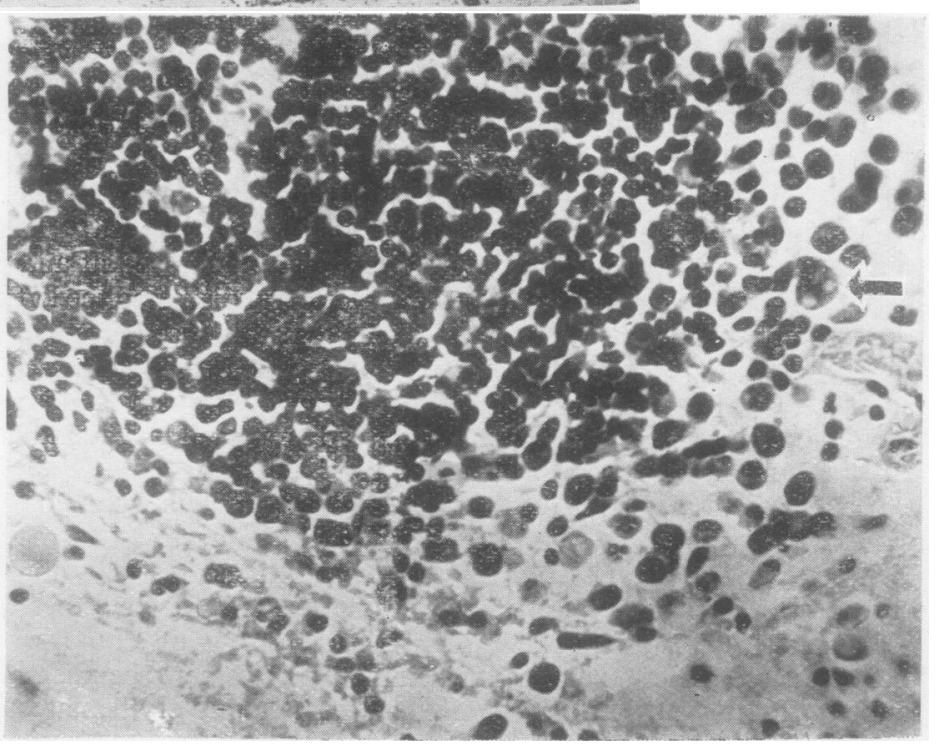


of the surface layer were necrotic (Fig. 1). Accompanying the hyperplasia, there were chronic inflammatory features, with marked congestion, oedema, and infiltration with lymphocytes, plasma cells, and histiocytes in that order of frequency. The cells were both diffuse and focal in distribution, with a distinct tendency to perivascular arrangement, particularly in the deeper parts of the synovial tissue and in the capsule (Figs 1, 2, and 3). Recent haemorrhage masked or distorted some of these features in several of the biopsies from the hips. Most of this, and probably much of the congestion in these specimens, was due to operative trauma, but the presence of haemosiderin in practically all the sections of synovial

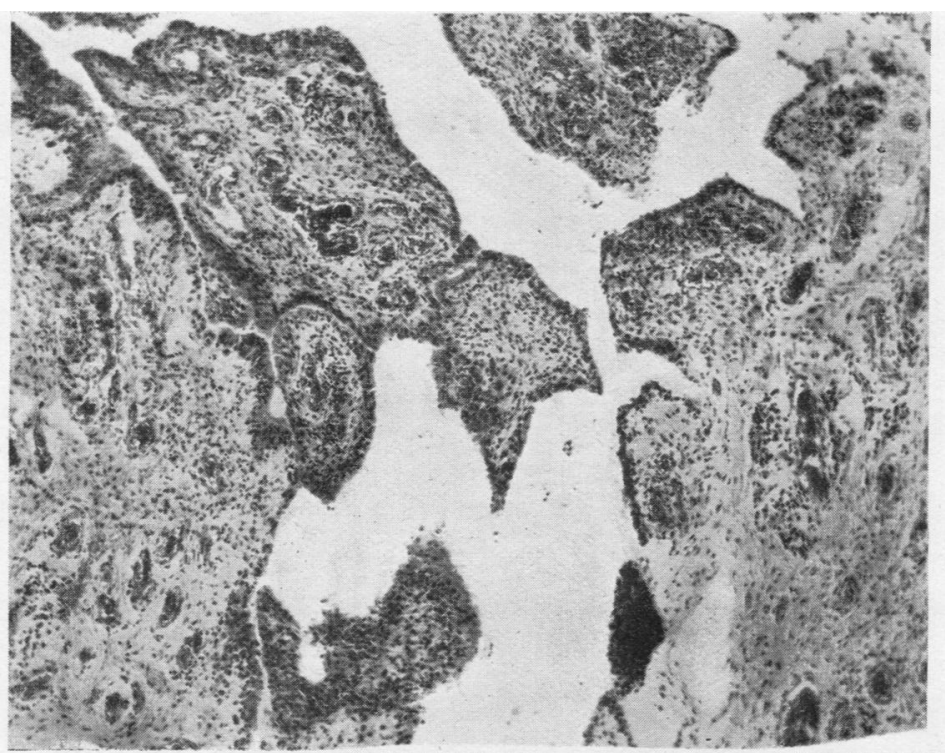

FIG. 3.- Synovial tissue from right hip. Proliferation of surface layer more striking and some giant cells visible at centre. ( $\times 50$.)

FIg. 4.-Synovial tissue from left knee. Marked fibrosis under surface (top), which has lost its lining layer. Fibrosis also present deeper. Focal round-cell infiltration still present. ( $\times 50$.)

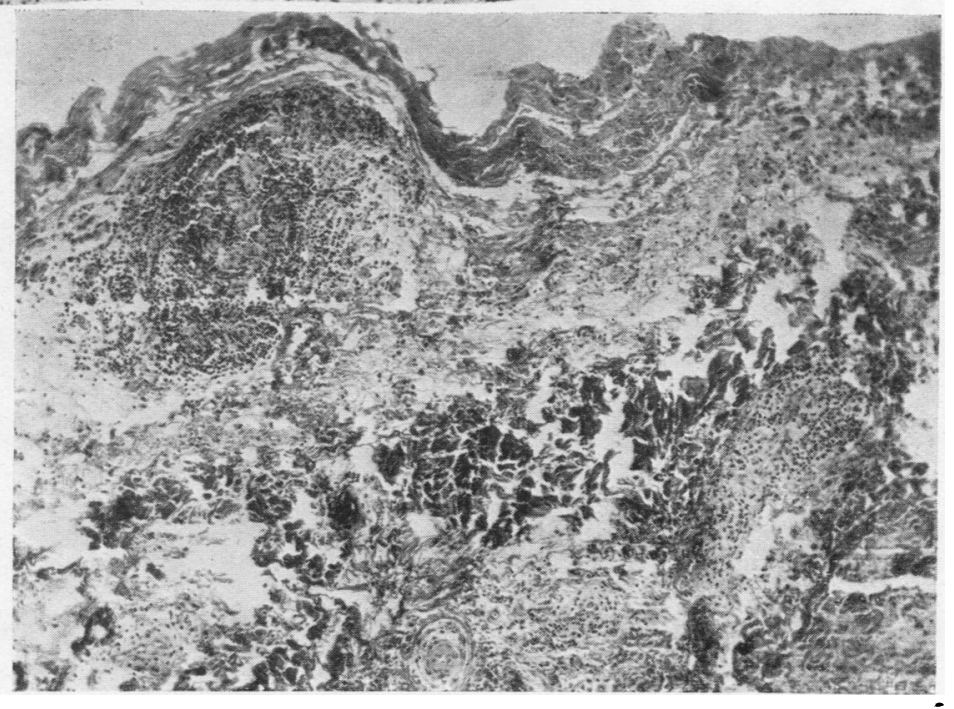


FIG. 5.-Synovial tissue from $\mathrm{R}$. or $\mathrm{L}$ hip. Fibrous tissue showing metaplasia to cartilage. $(\times 50$. $)$

Fig. 6.-Head of $\mathrm{right} f \mathrm{e} \mathrm{m} \mathrm{u}$. Articular surface mostly covered with thick layer of fibrous tissue. Tags of villous synovial tissue adhere to the neck.
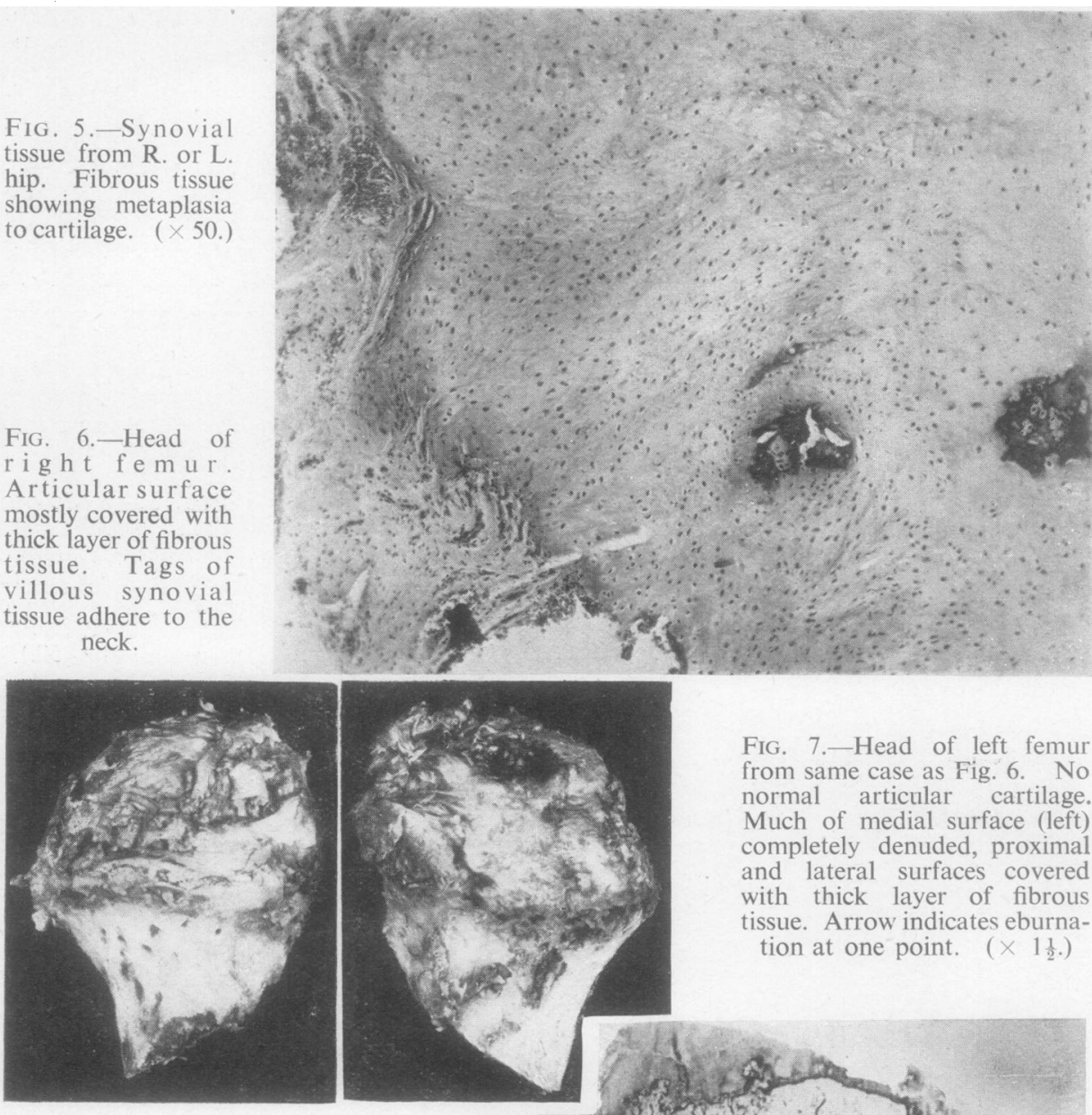

FIG. 7.- Head of left femur from same case as Fig. 6. No normal articular cartilage. Much of medial surface (left) completely denuded, proximal and lateral surfaces covered with thick layer of fibrous tissue. Arrow indicates eburnation at one point. $\left(\times 1 \frac{1}{2}\right.$.

tissue examined indicated that haemorrhage was a feature of the disease. Arterioles and small arteries frequently showed marked endarteritis obliterans and perivascular fibrosis. Several of the patients had received radiotherapy, so that some of these vascular changes were probably due to irradiation, rather than to the disease itself. At a later stage, fibrosis of the synovial tissue was a marked feature, but infiltration with

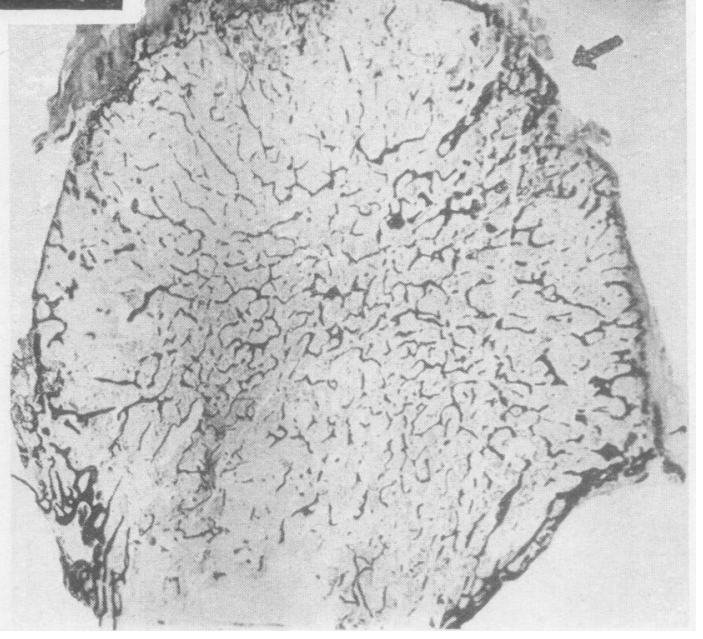


FIG. 8.-First postmortem case. Medial condyle of right femur. Articular cartilage being destroyed by granulation tissue on its free surface. Some bony replacement of deepest part of cartilage. $(\times 30$.
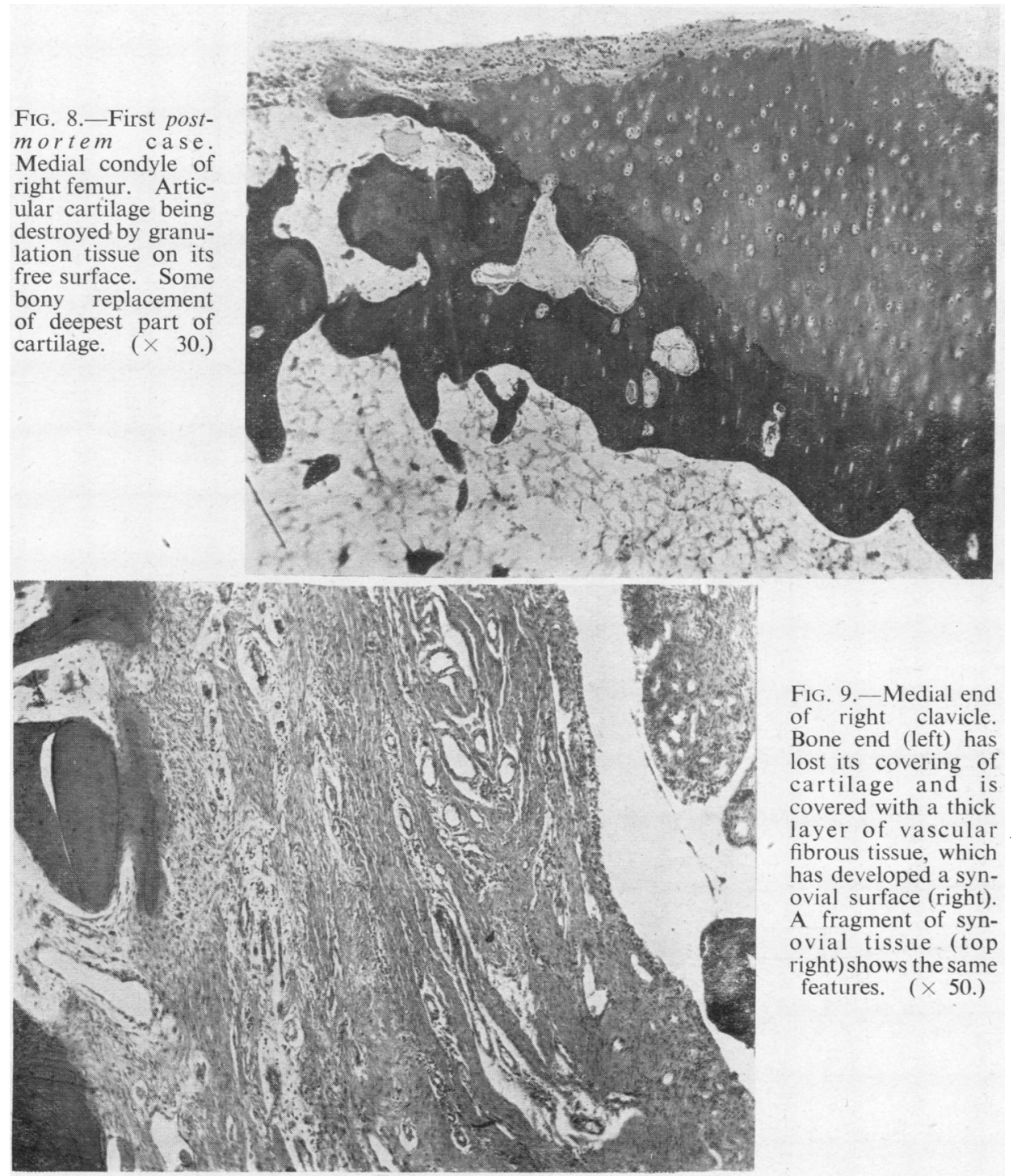

FIG, 9.-Medial end of right clavicle. Bone end (left) has lost its covering of cartilage and is covered with a thick layer of vascular fibrous tissue, which has developed a synovial surface (right). A fragment of synovial tissue (top right) shows the same features. $(\times 50$.

chronic inflammatory cells was still seen (Fig. 4, p. 395), and vascularity was greater than normal (Fig. 9). Later still, when signs of inflammation were disappearing, the fibrous tissue showed foci of metaplasia to cartilage and bone (Fig. 5).

Articular Cartilage and Bone.-The articular cartilage became covered with a layer of granulation tissue continuous with the proliferating synovial tissue, and of variable thickness and constitution. Inflammatory changes predominated in the earlier stages (Figs 8 and 10), to be replaced gradually by fibrous tissue (Figs 6, 7, and 9), in which foci of metaplasia occurred as already described. In 


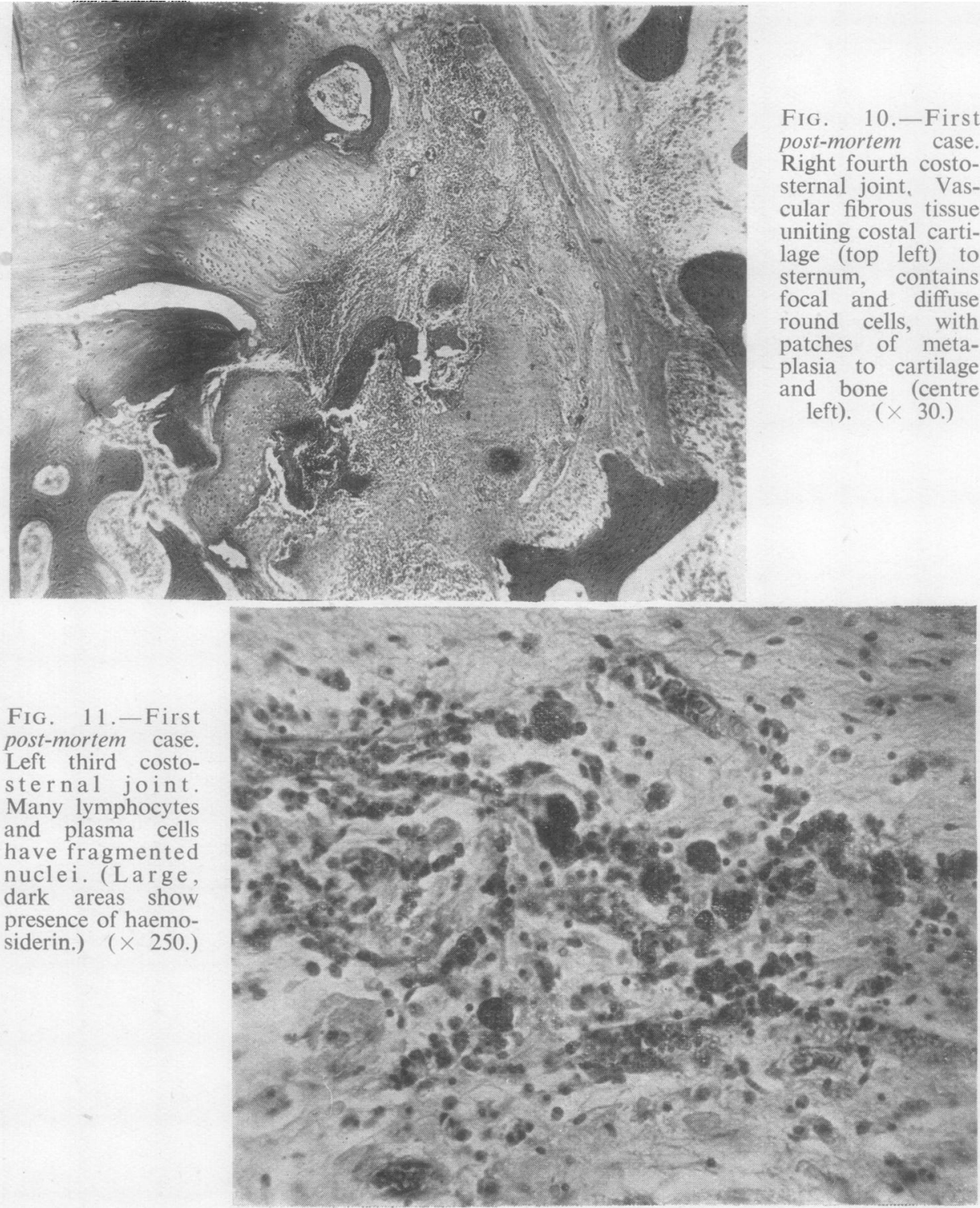

two cases, a simple synovial surface had developed on the free surface of this granulation tissue (Fig. 9). The underlying cartilage was gradually destroyed and, when bone was reached, this suffered the same fate. Penetration of the subchondral plate and invasion of the adjacent cancellous spaces were sometimes seen without extensive destruction of the bone (Figs 9 and 10). Focal infiltration with lymphocytes and plasma cells was common in cancellous spaces in bones near affected joints, even in the absence of penetration of granulation tissue into the 


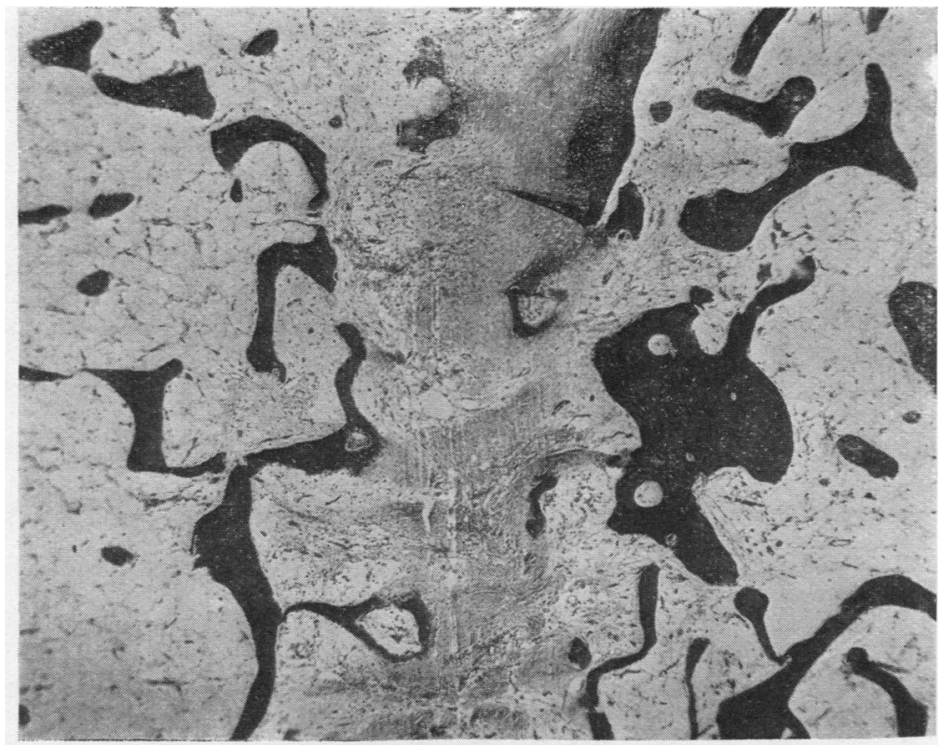

FIG. 12.-First postmortem case. Right medial cuneiformfirst metatarsal joint. Almost complete destruction of cartilage and ankylosis by fibrous tissue. ( $\times 25$.)

FIG. 13.-First postmortem case. Left tenth costo-vertebral joint. In the upper part of the figure, the joint has been replaced by fibrous tissue. Below this a partial joint space may be seen. $(x 4$.

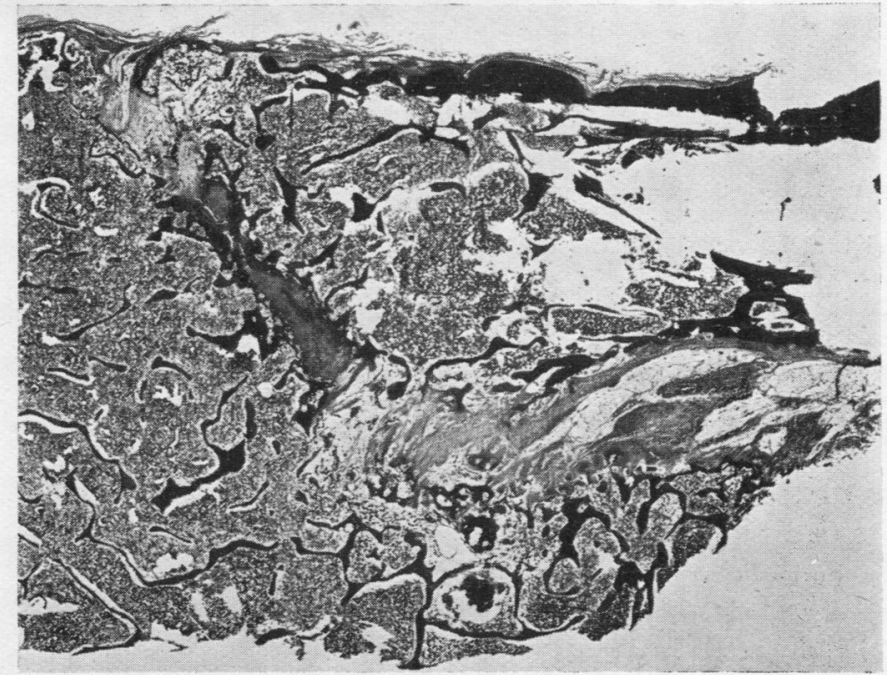

bone. Endarteritis obliterans was particularly marked in this situation in the sternoclavicular joint of one case, but this joint had been irradiated. The presence of large numbers of fragmented plasma cells in this case was probably also an irradiation effect (Fig. 11). Considerable atrophy of the cancellous bone in the neighbourhood of affected joints was a constant feature (Figs 7 and 12). In the single biopsy from the sacro-iliac joint, a little granulation tissue was present over the surface of the hyaline cartilage, but no synovial tissue proper was seen. A good deal of well-formed fibrous tissue between two surfaces covered by hyaline cartilage probably represented normal intra-articular ligaments. It was difficult to be certain of this, for the specimen was small and not easy to orientate. 


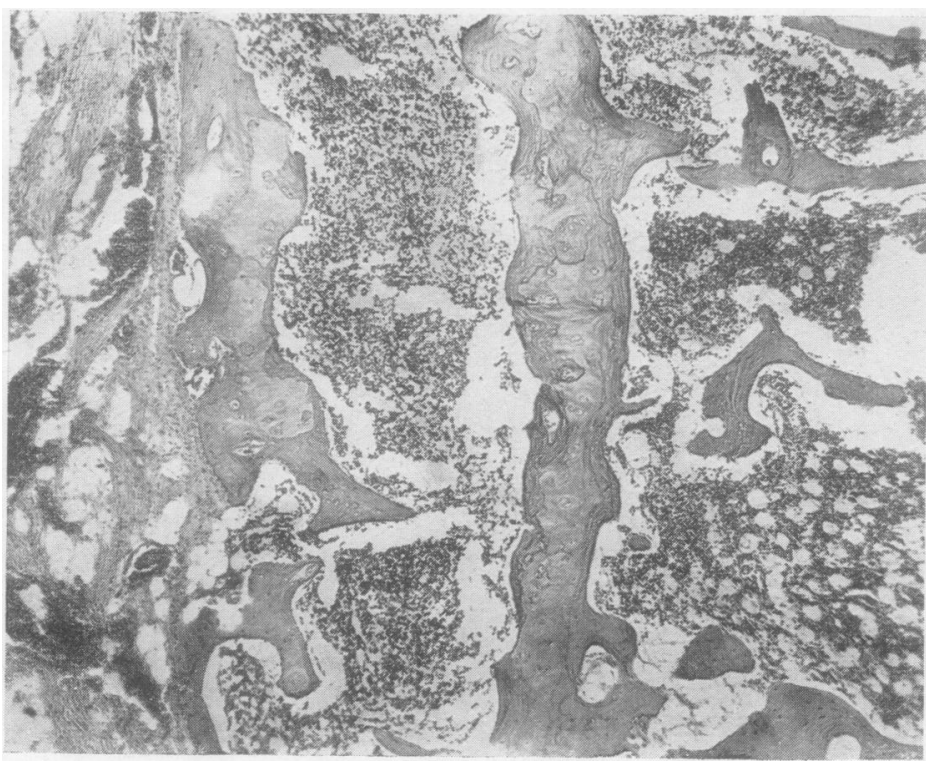

Fig. 14.-First postmortem case. Joint between third and fourth lumbar vertebrae on left side. Joint space contains haemopoietic marrow, and remnants of articular cartilage are undergoing direct metaplasia to bone. $(\times 30$.

The late stages were characterized by ankylosis, which was usually of mixed fibrous and bony, or purely bony, type (Figs 12, 13, 15, 16, 17, 18). Evidence of metaplasia to bone was seen even in those joints in which the bones were joined mainly by fibrous tissue (Fig. 12). In the final stage, practically none of the original joint tissues persisted, their place being taken by cancellous bone with haemopoietic marrow. Scattered islands of cartilage, undergoing gradual replacement by bone, were the only indication of the position of the joint (Figs 14 and 18). In those cases where ankylosis was partial or absent, changes of osteoarthritis were superimposed; namely, eburnation of exposed bone with marginal osteophytes (Fig. 7).

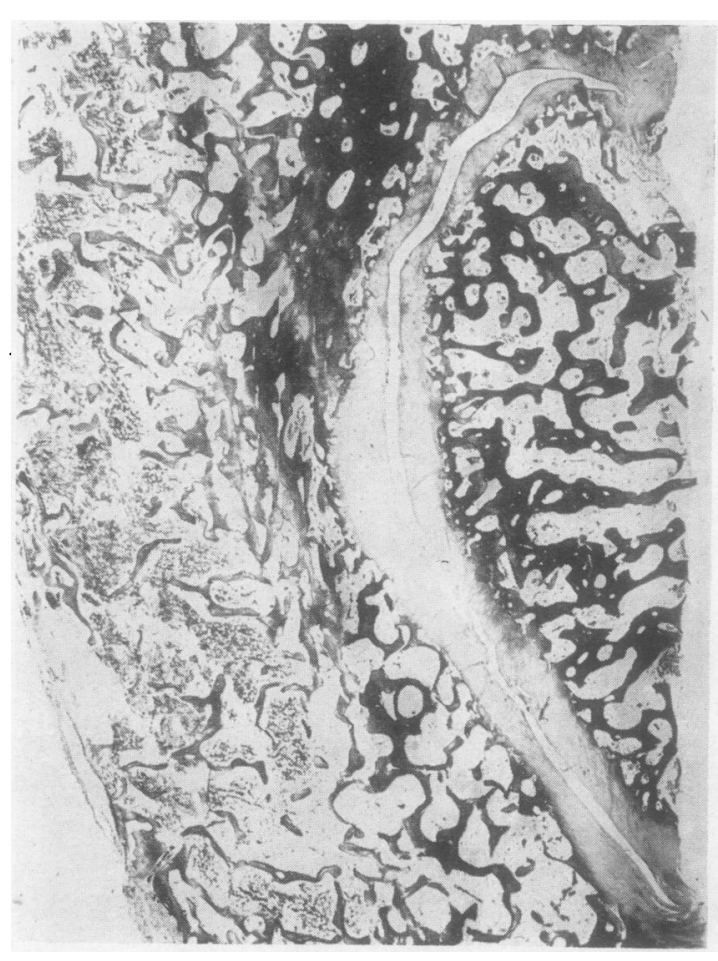

Fig. 15.-Normal lumbar intervertebral joint. $(\times \quad 7$. 
FIG. 16.-First postmortem case. Right sacro-iliac joint, sawn open by a coronal cut. Only a few islands of cartilage remain. Arrows indicate joint line.
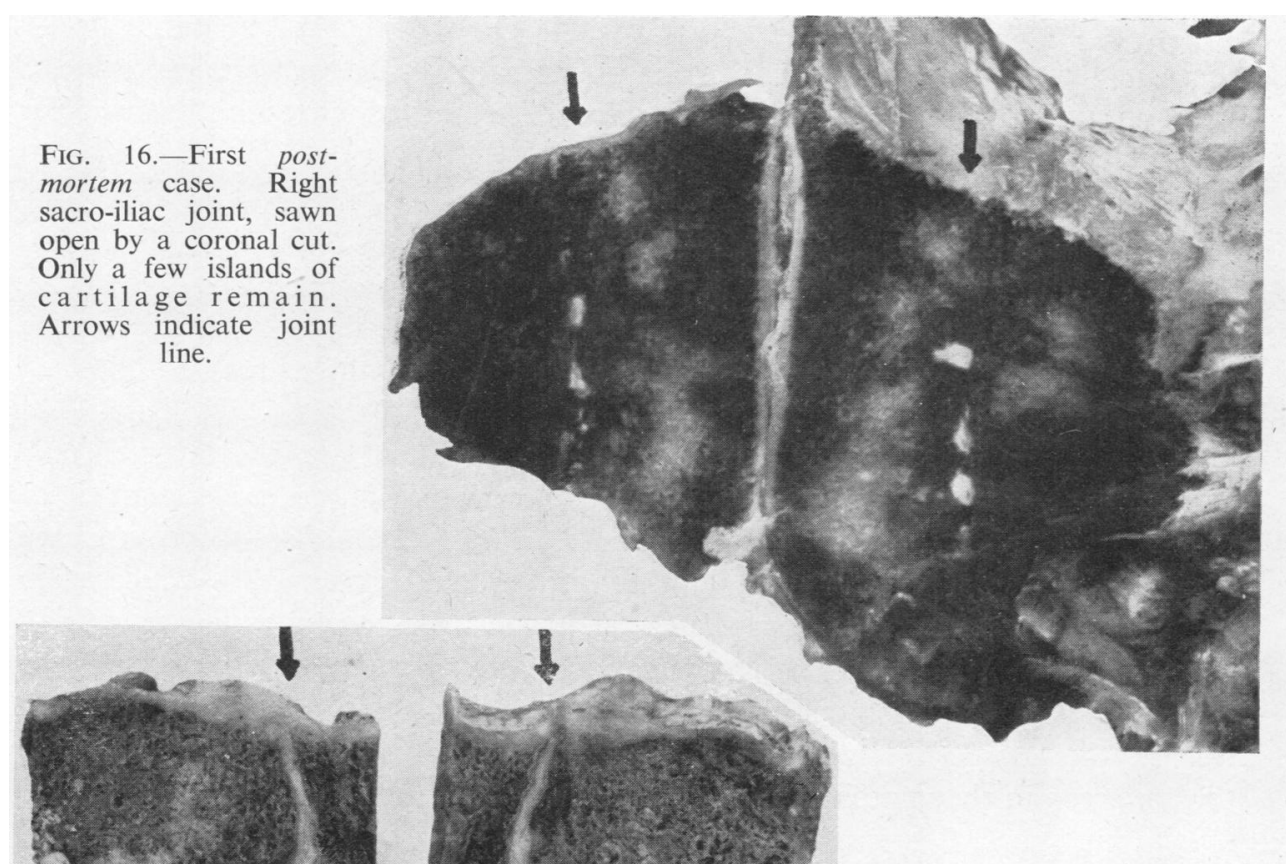

Fig. 17.- Normal sacroiliac joint, opened in the same way as specimen in Fig. 16.

FIG. 18.-First post-mortem case. Left sacro-iliac joint. Vertical section showing single remaining cartilaginous plate. $(\times 7$. 
Other Joint Structures.-The joint capsule showed changes in parallel with those in the synovial tissue, though the inflammatory changes were less marked. Intra-articular ligaments and menisci were destroyed along with the articular cartilages.

\section{Discussion}

It has been possible to trace the sequence of events in the diarthrodial joints in ankylosing spondylitis. Although none of the cases examined was early in the chronological sense, this is a disease of slow progression, characterized by phases of increased activity, so that material representing active phases may be obtained long after the first onset of the disease.

The disease apparently begins in the synovial tissue as a subacute or chronic inflammation, associated with proliferation, producing an excessive number of villi with a thickened lining of synovial cells. Proliferation also occurs over the surface of the articular cartilage and other intra-articular structures. Granulation tissue* is formed which destroys the cartilage and later penetrates the underlying bone. Opposing layers of this granulation tissue frequently become adherent and, as the inflammation subsides, firm fibrous ankylosis is established. In this disease, the ankylosis usually becomes bony. These features are closely similar to those seen in rheumatoid arthritis and are the basis for the current opinion that ankylosing spondylitis is a variant of rheumatoid arthritis (Dunham and Kautz, 1941; Polley and Slocumb, 1946; Collins, 1949).

There can be no doubt that the lesions in the diarthrodial joints in the two diseases are very alike. It has been possible to match all the stages of ankylosing spondylitis with sections from cases of rheumatoid arthritis. Although the process was more intense in several of the cases of rheumatoid arthritis, the differences are of degree only and probably reflect greater activity of the disease in these cases. Certain minor differences, however, were seen between the two conditions. Firstly, there was a greater tendency to haemorrhage in ankylosing spondylitis, perhaps due to the earlier formation of adhesions which were broken down on subsequent movement. Secondly, thickening of small vessels, usually in the form of endarteritis obliterans, was more marked in ankylosing spondylitis, even in joints which had not been irradiated. In those which had been irradiated, it was often a prominent feature. Thirdly, spondylitis is characterized clinically by a marked tendency to ankylosis soon after the involvement of a joint, and this process often goes on to bony fusion of the joint, as seen in radiographs. This was reflected in the pathological material examined. On the other hand, bony ankylosis is quite uncommon in rheumatoid arthritis.

The close resemblance between the joint lesions in the two diseases is open to two alternative interpretations:

(a) that ankylosing spondylitis and rheumatoid arthritis are variants of one disease,

* It is unfortunate that the term " pannus" is generally reserved for the tissue found on the surface of the articular cartilage in rheumatoid arthritis only, for the same process is seen in various other chronic arthritides, such as tuberculosis and chronic septic arthritis. "Pannus" is merely granulation tissue flattened out by its anatomical position. 
(b) that they are separate diseases, the pathological lesions representing a common reaction to different aetiological factors.

The former argument is based mainly on this resemblance in the pathology. The two conditions differ in respect of sex incidence, anatomical distribution of the lesions in typical cases, and response to therapeutic measures. In a few cases, such as the first post-mortem case in this study, ankylosing spondylitis involves peripheral limb joints as well as axial and limb girdle joints. If such cases are seen only in the late stages, the clinical resemblance to rheumatoid arthritis is striking. In the most cases of this type, however, the early stages of the disease are clinically typical of spondylitis. Pathologically also, there are differences, for the characteristic subcutaneous nodules of rheumatoid arthritis have not been encountered in ankylosing spondylitis. The muscle and nerve lesions which were seen in a high proportion of cases of the former type (Cruickshank, 1952), were seen only rarely in cases of the latter type.

On the other hand, there are numerous examples of conditions due to differing aetiological factors in which the lesions resemble one another closely. Furthermore, changes in the synovial tissue identical with, or closely resembling, those of ankylosing spondylitis and rheumatoid arthritis were seen in patients in whom both diseases could be excluded. Such changes were seen in one case of systemic lupus erythematosus, in eleven of non-rheumatic arthritis, in one of bursitis, and in seven of non-specific tenosynovitis. Another 21 of the 78 cases of non-specific tenosynovitis showed some or all of the features seen in the synovial tissue in ankylosing spondylitis and rheumatoid arthritis. In these cases the clinical notes were not available, but in all of them the tenosynovitis appears to have been an isolated process. Tenosynovitis is quite unusual in rheumatoid arthritis or ankylosing spondylitis, having been noted only once in several hundred cases seen in the last three years at the Rheumatic Unit, Northern General Hospital, Edinburgh.

The similarity between the histopathology of the diarthrodial joints in ankylosing spondylitis and rheumatoid arthritis can, therefore, be explained as a common response to different, but perhaps related, aetiological factors. Until more is known about these factors, it does not seem justifiable to classify ankylosing spondylitis as a variant of rheumatoid arthritis.

\section{Summary}

(1) Tissue was examined from diarthrodial joints from twelve cases of ankylosing spondylitis, 42 cases of rheumatoid arthritis, and 42 cases of other rheumatic diseases, and also from joints, tendon sheaths, and bursae from 397 cases of nonrheumatic diseases.

(2) The lesions found in ankylosing spondylitis were: subacute or chronic inflammation and hyperplasia of the synovial tissue; destruction of articular cartilage and other intra-articular tissues by granulation tissue. In the later stages, ankylosis, usually of bony type, occurred.

(3) The pathological changes in the diarthrodial joints in ankylosing spondylitis resemble very closely those of rheumatoid arthritis, but the two diseases differ 
in other important respects. Changes identical with those of ankylosing spondylitis and rheumatoid arthritis, or closely resembling them, were seen in joints, bursae, and tendon sheaths in cases where both diseases could be excluded.

(4) The classification of ankylosing spondylitis as a variant of rheumatoid arthritis is not justifiable until more is known about the aetiology of the two diseases.

This work was carried out during the tenure of a research grant from the Nuffield Foundation. I wish to thank Professor A. M. Drennan for providing facilities, and Dr. R. F. Ogilvie for advice and criticism. The sections were prepared by Mr. E. Kaminski and the photographs taken by Mr. T. C. Dodds.

\section{REFERENCES}

Collins, D. H. (1949). “The Pathology of Articular and Spinal Diseases", pp. 313-327. Arnold, London.

Cruickshank, B. (1952). J. Path. Bact. 64, -. (In the press.)

Dunham, C. L., and Kautz, F. G. (1941). Amer. J. med. Sci., 201, 232.

Freund, E. (1942). Edin. med. J., 49, 91.

Güntz, E. (1933). Fortschr. Röntgenstr., 47, 683.

Polley, H. F., and Slocumb, C. H. (1947). Annals of the Rheumatic Diseases, 6, 95.

\section{L'histopathologie des diarthroses dans la spondylite ankylosante}

\section{RÉSUMÉ}

(1) On a examiné les tissus des diarthroses dans 12 cas de spondylite ankylosante, 42 cas d'arthrite rhumatismale, et 42 d'autres maladies rhumatismales, ainsi que les tissu provenant d'articulations, de gaines tendineuses et de membranes synoviales de 397 cas de maladies rhumatismales.

(2) On a trouvé dans la spondylite ankylosante les lésions suivantes: inflammation subaiguë ou chronique et hyperplasie du tissu synovial, destruction par le tissu de granulation du cartilage articulaire et des autres tissus intra-articulaires. A une période ultérieure il se produisait une ankylose, généralement du type osseux.

(3) Les altérations pathologiques dans les diarthroses des cas de spondylite ankylosante ressemblaient de très près à celles des cas d'arthrite rhumatismale, mais ces deux maladies différaient entre elles par d'autres aspects importants. Des altérations identiques ou bien fort similaires à celles de la spondylite ankylosante et de l'arthrite rhumatismale ont été observées dans les articulations, les synoviales et les gaines tendineuses des cas où les deux maladies ont pu être exclues.

(4) La classification de la spondylite ankylosante comme une variante de l'arthrite rhumatismale n'est pas justifiable jusqu'à ce qu'on connaisse mieux l'étiologie de ces deux maladies.

\section{La histopatologia de las diartrosis en la espondilitis anquilosante}

\section{Sumario}

(1) Se ha examinado los tejidos de las diartrosis en 12 casos de espondilitis anquilosante, en 42 casos de artritis reumatoide, y en 42 casos de otras enfermedades reumáticas, as como los tejidos procedentes de articulaciones, de vainas tendinosas y de membranas sinoviales de 397 casos de enfermedades otras que reumáticas.

(2) Las lesiones siguientes fueron encontradas en la espondilitis anquilosante: inflamación subaguda o crónica e hiperplasia del tejido sinovial, destrucción por el tejido de granulación del cartilago articular y de otros tejidos intra-articulares. En los periódos avanzados hubo anquilosis, generalmente de tipo óseo.

(3) Las alteraciones patológicas en las diartrosis de los casos de espondilitis anquilosante se parecían mucho a las observadas en los casos de artritis reumatoide, pero estas dos enfermedades diferían entre sí por otros aspectos importantes. Alteraciones idénticas o muy similares a las de la espondilitis anquilosante y de la artritis reumatoide fueron observadas en articulaciones, sinovias y vainas tendinosas de los casos en que la existencia de ambas enfermedades había podido excluirse.

(4) La clasificación de la espondilitis anquilosante entre las variantes de la artritis reumatoide no es justificable mientras no se conozca la etiología de ambas enfermedades. 